\title{
Reducing the Effects of Blood Sugar Infusion of Melastoma Malabathricum L. in Mus Musculus
}

\author{
Le Cong Truong
}

Faculty of Chemical Engineering, Ho Chi Minh City University, Vietnam

Received: August 2, 2020

Received in Revised: August 10, 2020

Accepted August 13, 2020

\begin{abstract}
This study aims to determine the blood sugar-lowering effect of Melastoma malabathricum L. infusion on Mus musculus. The research design used was an experimental laboratory carried out in the pharmacology laboratory of the Ho Chi Minh City University. This study used 15 male mice which were divided into 5 groups consisting of group I as negative control by giving aquadest, groups II, III, IV were given infusion of Melastoma malabathricum L. respectively 0.1 $\mathrm{g} / \mathrm{ml}, 0.2 \mathrm{~g} / \mathrm{ml}$, and $0.4 \mathrm{~g} / \mathrm{ml}$, and group $\mathrm{V}$ as a positive control with glibenclamide suspension. The results showed that statistical testing using the SPSS program showed a significant difference ( $\mathrm{p}<0.05$ ), which means that senggani leaf infusion had a significant effect on reducing blood sugar levels in mice and the most optimal was $0.4 \mathrm{~g} / \mathrm{ml}$ infusion.
\end{abstract}

Keywords: Infusion, Blood Sugar, Mice

\section{Introduction}

Hyperglycemia is a degenerative disease whose incidence is quite high in various countries and is a disease that is a public health problem. Hyperglycemia is a condition of increased blood glucose from normal fasting levels of $80-90 \mathrm{mg} / \mathrm{dl}$ of blood, or non-fasting ranges of around 140-160 mg / dl of blood (Hotchkiss, 2003).

Most cases of hyperglycemia will usually progress to diabetes mellitus (DM) with the support of clinical examinations such as fasting blood sugar levels above $126 \mathrm{mg} / \mathrm{dl}$ and blood sugar levels 2 hours after eating above $200 \mathrm{mg} / \mathrm{dl}$ (Ban, 2001; Visser et al, 2015; Jeffreys et al, 2012). Diabetes mellitus is classified into 2 types, namely diabetes mellitus type I (DM I), which occurs because the pancreas cannot produce insulin or commonly called insulin dependence, and diabetes mellitus type 2 (DM II), which means the body can still produce insulin, but the insulin it produces not enough so that it can still be treated with oral drugs (Mellitus, 2005).

Therapy with synthetic drugs often fails, partly due to side effects and high costs due to longterm treatment. Therapy with alternative medicines from medicinal plants that have antihyperglycemic effects is a good treatment option, in addition to the lack of side effects, it can also increase the chances of recovery, at least with controlled blood glucose levels (Marianne et al, 2011). One of the traditional treatments for diabetes mellitus is using plants. Medicinal plants are thought to have compounds that are efficacious as antidiabetic mellitus. According to Johnny et al. (2010) and Farnsworth et al. (1985), Melastoma malabathricum L. have several chemical compounds including flavonoids, saponins, tannins, alkaloids, steroids, phenolics, triterpenoids, and glycosides which are also thought to have potential as oral antidiabetic. Many natural 
flavonoids play an important role in the prevention of diabetes and its complications. A number of studies have been conducted to demonstrate the hypoglycemic effect of flavonoids using different experimental models, the result is that plants containing flavonoids have been shown to have beneficial effects in fighting diabetes mellitus (Brahmachari, 2011).

Based on research conducted by Ayu Lestari in 2016 on "Test of the Anti-Inflammatory and Analgetic Effects of Senggani Leaf Infusion (Melastoma malabathricum L.), it shows that senggani leaf infusion with a concentration of $10 \%, 20 \%$, and $40 \%$ has an analgesic effect on mice. (Mus musculus). Based on the description above, a study was conducted to determine the blood sugar-lowering effect of senggani leaf infusion at concentrations of $0.1 \mathrm{~g} / \mathrm{ml}, 0.2 \mathrm{~g} / \mathrm{ml}$, and $0.4 \mathrm{~g} / \mathrm{ml}$ on mice (Mus musculus). the ethanol extract of Melastoma malabathricum $\mathrm{L}$. could reduce blood sugar levels at a dose of $180 \mathrm{mg} / \mathrm{g} \mathrm{BW}$ and $360 \mathrm{mg} / \mathrm{g} \mathrm{BW}$.

\section{Classification of Melastoma malabathricum L. (Van Steenis, 1975)}

Senggani including shrubs, 0.5-4 m high. young scaly branches. Leaves stemmed, opposite, elongated or oval elongated with pointed tips, bony leaves 3,2-20 times 1-8 cm, both sides hairy. Flowers together 5-18, at the tip and axillary of the highest leaf, spelled 5 (4-6). The petal tube is bell-shaped, scaly, taju with a number of small teeth. The protective leaves are scaly, slender, 5 by $2 \mathrm{~mm}$, do not cover the buds. Leaves ovate inverted, $2-3 \mathrm{~cm}$ long, red purple, rarely white. Stamens 10 (8-12), extending from the link from under the anthers in the long 6-16 mm stamens, 2-7 $\mathrm{mm}$ in short ones. ovule 5 (4-6), connected by a grid against the petal tube. The fruit of the buni is in the form of a pot, opening irregularly across the way, from which the dark red seed frame breaks. Shell-shaped seeds. Senggani can grow in grass, small forest shrubs 5-2000 m (Van Steenis, 1975)

\section{Chemical Ingredients}

The chemical content of senggani plants in part are flavonoids, phenols, steroids / triterpenoids, 4.3\% tannins. The leaves contain saponins (Farnsworth et al, 1985). Chemical Ingredients The chemical content of senggani plants in part are flavonoids, phenols, steroids / triterpenoids, $4.3 \%$ tannins. The leaves contain saponins (Farnsworth et al, 1985).

\section{Benefit}

The use of the senggani plant as a traditional medicine has experienced many developments, since it was originally used only as an anti-diarrhea but now has various kinds of properties. The existence of a bitter taste of senggani can be effective as a fever reliever (antipyretic), pain reliever (analgesic), urinary laxative (diuretic), eliminates swelling, improves blood flow, and stops hemostatic bleeding). Senggani is generally used by the community to treat vaginal discharge, indigestion, dysentery, diarrhea, canker sores and uterine bleeding (Farnsworth et al, 1985). According to Johnny et al. (2010) and Farnsworth et al. (1985), Melastoma malabathricum L. have several chemical compounds including flavonoids, saponins, tannins, alkaloids, steroids, phenolics, triterpenoids, and glycosides which are also thought to have potential as oral antidiabetic.

\section{Infusion}

Infusion is a liquid preparation that is made by extracting vegetable simplicia with water at $90^{\circ}$ $\mathrm{C}$ for 15 minutes. The infusion method is used because infusion is a simple preparation 
commonly used in the manufacture of traditional medicines and is easy to apply in the community (Arukwe et al., 2012).

Making Infusion is the simplest way to make herbal preparations from soft ingredients such as leaves and flowers. Can be drunk hot or cold. Herbal preparations containing essential oils will be less effective if they do not use a cover for making infusions. Then to see the temperature of the infudation according to the provisions, stirring is carried out, then the temperature is measured with a thermometer. The infusion device is in the form of a double-decker pot, the bottom pan filled with water whose heating will boil at a temperature of $100 \mathrm{C}$. While the second pot is filled with simplicia and water, during the heating process the simplicia water does not boil but reaches a temperature of $90^{\circ} \mathrm{C}$.

The advantage of this method is that the equipment is simple and the time required is quite short. While the disadvantages include the loss of essential substances, the presence of substances that are not heat resistant and substances containing albumin which cause the withdrawal of these nutritious substances (García-Sevillano et al, 2015).

\section{Classification of Test Animals (Malole, 1989)}

\section{Morphology}

Mus musculus mice are fast-breeding rodents (Rodentia), are easy to maintain in large numbers, have a large genetic variation and their anatomical and physiological characteristics are well characterized (Malole, 1989).

\section{Hyperglycemic}

Hyperglycemia is a degenerative disease whose incidence is quite high in various countries and is a disease that has become a public health problem (Ministry of Health, 2015). Hyperglycemia is a condition of increasing blood glucose from normal fasting levels of $80-90 \mathrm{mg} / \mathrm{dl}$ of blood, or non-fasting ranges of around 140-160 mg / dl of blood (Hotchkiss, 2003).

Most cases of hyperglycemia will usually progress to diabetes mellitus (DM) with the support of clinical examinations such as fasting blood sugar levels above $126 \mathrm{mg} / \mathrm{dl}$ and blood sugar levels 2 hours after eating above $200 \mathrm{mg} / \mathrm{dl}$ (Ban, 2001; Visser et al, 2015; Jeffreys et al, 2012).

\section{Epidemiology}

The World Health Organization (WHO) states that 347 million people in the world are diagnosed with DM. WHO estimates that DM will be the seventh leading cause of death worldwide in 2030. The prevalence of DM in the world is estimated to be around $6.4 \%$ in 2010 and is predicted to increase to $7.7 \%$ in 2030 . Most of the increase in the prevalence of DM occurs in the country. developing (JE Shaw, et al. 2010).

\section{Pathogenesis}

If the amount or function of insulin is deficient, hyperglycemia will arise, causing diabetes. Insulin deficiency can be absolute if the pancreas does not produce insulin at all or produces insulin, but in insufficient amounts, for example, what occurs in type 1 diabetes. Insulin deficiency is said to be relative if the pancreas produces insulin in normal amounts, but the insulin does not work effectively. This occurs in people with type 2 diabetes, where insulin resistance has occurred. Both absolute and relative insulin deficiency will result in metabolic disorders, to carry out its functions, build new tissue, and repair tissue. The hormone insulin is an 
anabolic hormone that promotes the storage of nutrients, storage of glucose as glycogen in the liver and muscles, changes in glucose to triaciglycerol in the liver and its storage in adipose tissue, and absorption of amino acids and protein synthesis in skeletal muscle.

This hormone also increases the synthesis of albumin and other blood proteins by the liver. Insulin increases the use of glucose as fuel by stimulating glucose transport into muscle and adipose tissue. The hormone insulin is a polypeptide hormone that is synthesized by endocrine pancreatic beta cells consisting of microscopic groups of small glands or islets of Langerhans, scattered throughout the exocrine pancreas. Insulin acts on fat, and protein, and this action basically aims to change the direction of the metabolic pathway so that sugars, fats, and amino acids can be stored and do not burn out. If there is no insulin, fat, sugar, and amino acids cannot enter the cells so that these nutritional elements remain in the plasma. As a result, the body's cells undergo starvation and there is an increase in glucose, cholesterol, and fat levels. Apart from blood glucose levels, other factors such as amino acids, fatty acids, and gastro-intestinal hormones stimulate insulin secretion to varying degrees.

The main metabolic function of insulin is to increase the speed of glucose transport through cell membranes to tissues, especially muscle cells, fibroblasts and fat cells. According to the easy study book pharmacology (2003). Diabetes mellitus is not insulin dependent (Type 2) caused by decreased insulin release or decreased tissue response to insulin (eg decreased number of insulin receptors) resulting in hyperglycemia but not ketoacidosis. Type 2 diabetes mellitus is a chronic progressive disease, starting with insulin resistance leading to increased hepatic glucose production and ending with beta cell damage. Insulin resistance is defined as the inability of target tissues such as muscle and adipose tissue to respond to endogenous insulin secretion in the body (WHO, 2004).

Lipotoxicity can contribute to insulin resistance. Lipotoxicity refers to the high concentration of free fatty acids that occurs as a result of stress-sensitive lipase (HSL) hormones. Normally insulin inhibits lipolysis by inhibiting HSL, but insulin resistance does not occur efficiently. The result of increased lipolysis is an increase in free fatty acids, and this is what causes obesity and an increase in adipose. Free fatty acids cause insulin resistance by promoting serine phosphorylation at insulin receptors which can reduce the activity of the insulin signaling pathway. Phosphorylation of insulin receptors on the amino acid tyrosine is important for activating the insulin signaling pathway, otherwise GLUT-4 will fail to translocate, and glucose absorption into the tissue will decrease, causing hyperglycemia (Ahrén, 2003; Hu et al, 2001; Unger, 2008).

\section{Signs and symptoms}

\section{Acute Symptoms}

Symptoms of DM from one patient to another vary, and may not even show any symptoms until a certain time. At the beginning, the symptoms shown include a lot of things (tripoli), namely: a lot of eating (polyphagia), lots of drinking (polydipsia), a lot of urination (polyuria). If the condition is not treated promptly, there will be symptoms of appetite to begin to decrease, weight loss rapidly (loss of 5 - $10 \mathrm{~kg}$ in 2-4 weeks), and fatigue. If it is not treated quickly, it will cause nausea, and even the patient will fall into a coma which is called a diabetic coma. 


\section{Chronic Symptoms}

Chronic symptoms that are often experienced by DM sufferers are tingling, hot skin, or prickling, thick sensation in the skin, cramps, easy drowsiness, blurred eyes, itching around the genitals, especially women, teeth easily wobbly and easily loose, ability decreased sexual impotence.

\section{Glibenclamide}

Glibenclamide is an oral hypoglycemic sulfonyl urea derivative that works actively to reduce blood sugar levels. Glibenclamide works by stimulating insulin secretion from the pancreas. Therefore glibenclamide is only beneficial in adult diabetics whose pancreas is still capable of producing insulin on oral use, some of the glibenclamide is absorbed into the extracellular fluid and some is bound to plasma proteins. A single dose of glibenclamide will lower the blood for 3 hours and this level can last for 15 hours. Glibenclamide is excreted with feces and as a metabolite with urine. Glibenclamide stimulates beta cells of the pancreatic islets of Langerhans so that insulin secretion is increased. In addition, the sensitivity of beta cells to blood glucose levels is also increased by their influence on glucose transport proteins. There are indications that this drug also improves the sensitivity of the target organ for insulin and reduces absorption by the liver.

\section{Methods}

The population in this study were healthy mice (Mus musculus) with body weight ranging from 20-30 gl, the sample used in this study were 15 male mice (Mus musculus). Senggani (Melastoma malabathricum L.) leaves are fresh leaves, taken in the morning at 08.00-10.00, the leaves of senggani (Melastoma malabathricum L.) obtained are then sorted wet and then washed with running water, after that the leaves are chopped, then dried by aerating. After drying, the simplicia is powdered in a blender. The extract was made by the infudation method. Weigh the powder of senggani (Melastoma malabathricum L.) leaves as much as $10 \mathrm{~g}, 20 \mathrm{~g}$ and $40 \mathrm{~g}$ and add $100 \mathrm{ml}$ of water each. Then heated for 15 minutes starting from the temperature reaching 90 ${ }^{\circ} \mathrm{C}$ while stirring occasionally. Then filter it with a flannel cloth while hot enough through the dregs to obtain the desired infusion volume of $100 \mathrm{~mL}$. Weigh 1 gram of Na.CMC powder, then put it in $50 \mathrm{ml}$ of hot distilled water (temperature $70 \mathrm{oC}$ ) little by little while stirring rapidly so that a homogeneous colodial solution is formed.

After that, it is sufficient with distilled water to $100 \mathrm{ml} .20 \mathrm{~g}$ of glucose is dissolved in $100 \mathrm{ml}$ of aquadest while stirring until a homogeneous solution is formed. 10 tablets of $5 \mathrm{mg}$ glibenclamide tablet were put into the mortar then crushed then weighed to calculate the average weight. The tablet powder was weighed as much as $15.8 \mathrm{mg}$ then put into a glass beaker and suspended with $1 \% \mathrm{w} / \mathrm{v}$ Na.CMC then homogenized, then put into a $20 \mathrm{ml}$ volumetric flask and the volume was sufficient with Na.CMC $1 \% \mathrm{w} / \mathrm{v}$ solution to $20 \mathrm{ml}$. The test animals used as many as 15 animals were obtained from the calculation of the formula Federer $[(t-1)(n-1)>15]$, which was divided into 5 groups, each group consisting of 3 mice (Mus musculus) who are healthy with weight It has been weighed before and has been marked.

Before treatment, 15 mice (Mus musculus) were fasted for 3-4 hours and their fasting blood glucose levels were measured by cutting the tails of the mice and the blood was dripped on glucose strips, then given a glucose solution of $20 \% \mathrm{w} / \mathrm{v}$ orally with a volume of $1 \mathrm{ml} / 30 \mathrm{~g} \mathrm{BW}$ 
to increase blood glucose levels of mice until they are hyperglycemic ( $\geq 200 \mathrm{mg} / \mathrm{dl}$ ). After 60 minutes, the blood glucose level was measured.

Group I mice were given aquadest as a negative control, group II were given glibenclamide suspension as a positive control, groups III, IV, and V were given infusion of senggani (Melastoma malabathricum L.) leaves with a concentration of $0.1 \mathrm{~g} / \mathrm{ml}, 0$, respectively. $2 \mathrm{~g} / \mathrm{ml}$, and $0.4 \mathrm{~g} / \mathrm{ml}$ orally. After that, measurements of the blood glucose levels of mice (Mus musculus) were carried out at 30,60, and 90 minutes until they reached normal blood glucose levels, namely $62-175 \mathrm{mg} / \mathrm{dl}$. The glucometer is calibrated using a kide strip wrench and then the strip is attached to the instrument. Blood was stabilized through the veins at the tail end of the male mice and then dripped on a glucometer strip and it was automatically measured and the results read on a glucometer monitor. Data were collected from the results of measurements of the initial blood glucose levels of mice (Mus musculus), induced blood glucose levels, and after treatment of each group.

\begin{tabular}{|c|c|c|c|c|c|c|c|c|}
\hline \multirow[t]{2}{*}{ Treatment } & \multirow[t]{2}{*}{$\mathbf{R}$} & \multirow[t]{2}{*}{$\begin{array}{l}\text { Body } \\
\text { weight } \\
\text { (g) }\end{array}$} & \multirow[t]{2}{*}{$\begin{array}{l}\text { initial } \\
\text { sugar } \\
\text { levels }\end{array}$} & \multirow[t]{2}{*}{$\begin{array}{c}\text { Level } \\
\text { s } \\
\text { Suga } \\
\mathbf{r} \\
\text { Indu } \\
\text { ction }\end{array}$} & \multicolumn{3}{|c|}{$\begin{array}{c}\text { Blood sugar } \\
\text { levels } \\
\text { After giving the } \\
\text { test preparation } \\
\text { (minute) }\end{array}$} & \multirow[t]{2}{*}{$\begin{array}{c}\% \\
\text { Decline }\end{array}$} \\
\hline & & & & & 30 & 60 & 90 & \\
\hline \multirow{3}{*}{$\begin{array}{l}\text { Negative control } \\
\text { (aquadest) }\end{array}$} & 1 & 27,4 & 76 & 242 & 231 & 220 & 197 & 18,5 \\
\hline & 2 & 29,2 & 70 & 232 & 232 & 223 & 201 & 13,3 \\
\hline & 3 & 21,7 & 63 & 253 & 246 & 223 & 212 & 16,2 \\
\hline \multirow{3}{*}{$\begin{array}{l}\text { Senggani leaf } \\
\text { infusion } 0,1 \mathrm{~g} / \mathrm{ml}\end{array}$} & 1 & 19,5 & 99 & 298 & 254 & 200 & 139 & 53,3 \\
\hline & 2 & 24,9 & 129 & 307 & 241 & 192 & 167 & 45,6 \\
\hline & 3 & 22,1 & 138 & 299 & 249 & 210 & 159 & 46,8 \\
\hline \multirow{3}{*}{$\begin{array}{l}\text { Senggani leaf } \\
\text { infusion } 0,2 \mathrm{~g} / \mathrm{ml}\end{array}$} & 1 & 26 & 85 & 261 & 165 & 139 & 121 & 53,6 \\
\hline & 2 & 24,7 & 63 & 275 & 202 & 160 & 127 & 53,8 \\
\hline & 3 & 24,3 & 116 & 255 & 247 & 194 & 112 & 56,0 \\
\hline \multirow{3}{*}{$\begin{array}{l}\text { Senggani leaf } \\
\text { infusion } 0,4 \mathrm{~g} / \mathrm{ml}\end{array}$} & 1 & 27,1 & 71 & 238 & 128 & 96 & 89 & 62,2 \\
\hline & 2 & 28,3 & 92 & 241 & 95 & 76 & 70 & 70,9 \\
\hline & 3 & 26,8 & 98 & 234 & 117 & 110 & 86 & 63,2 \\
\hline \multirow{3}{*}{$\begin{array}{l}\text { Positive control } \\
\text { Glibenclamide }\end{array}$} & 1 & 24,5 & 108 & 204 & 130 & 70 & 61 & 70,0 \\
\hline & 2 & 23,8 & 92 & 264 & 115 & 77 & 63 & 76,1 \\
\hline & 3 & 27,4 & 94 & 234 & 160 & 92 & 71 & 69,6 \\
\hline
\end{tabular}

Table 2. The average percentage of reduction in blood sugar levels of mice after 90 minutes

\begin{tabular}{|c|l|l|l|l|l|}
\hline \multirow{2}{*}{$\begin{array}{c}\text { Replication } \\
\text { of mice }\end{array}$} & \multicolumn{5}{|c|}{ Percent blood sugar lowering effect after 90 minutes } \\
\cline { 2 - 6 } & $\begin{array}{l}\text { Negative } \\
\text { control } \\
\text { (Aquadest) }\end{array}$ & $\begin{array}{l}\text { Senggani } \\
\text { leaf } \\
\text { infusion } \\
0.1 \mathrm{~g} / \mathrm{ml}\end{array}$ & $\begin{array}{l}\text { Senggani } \\
\text { leaf } \\
\text { infusion } \\
0,2 \mathrm{~g} / \mathrm{ml}\end{array}$ & $\begin{array}{l}\text { Senggani } \\
\text { leaf } \\
\text { infusion } \\
0,4 \mathrm{~g} / \mathrm{ml}\end{array}$ & $\begin{array}{l}\text { Positive Control } \\
\text { (Glibenclamide) }\end{array}$ \\
\hline 1 & 18,5 & 53,3 & 53,6 & 62,2 & 70,0 \\
\hline 2 & 13,3 & 45,6 & 53,8 & 70,9 & 76,1 \\
\hline
\end{tabular}




\begin{tabular}{|c|c|c|c|c|c|}
\hline 3 & 16,2 & 46,8 & 56,0 & 63,2 & 69,6 \\
\hline Total \% & $\mathbf{4 8}$ & $\mathbf{1 4 5 , 7}$ & $\mathbf{1 6 3 . 4}$ & $\mathbf{1 9 6 , 3}$ & $\mathbf{2 1 5 , 7}$ \\
\hline Average \% & $\mathbf{1 6}$ & $\mathbf{4 8 , 5}$ & $\mathbf{5 4 . 4}$ & $\mathbf{6 5 , 4}$ & $\mathbf{7 1 , 9}$ \\
\hline
\end{tabular}

\section{Result and Discussion}

Hyperglycemia is a condition of increased blood glucose from normal fasting levels of 80 - 90 $\mathrm{mg} / \mathrm{dl}$ of blood, or non-fasting ranges of around 140-160 mg / dl of blood (Hotchkiss, 2003). Most cases of hyperglycemia will usually progress to diabetes mellitus (DM) with the support of clinical examinations such as fasting blood sugar levels above $126 \mathrm{mg} / \mathrm{dl}$ and blood sugar levels 2 hours after eating above $200 \mathrm{mg} / \mathrm{dl}$.

The research entitled "Blood Sugar Lowering Effect of Senggani Leaf Infusion (Melastoma malabathricum L.) on mice (Mus musculus) was conducted with the aim of knowing the blood sugar-lowering effect of senggani (Melastoma malabatricum L.) leaf infusion on mice (Mus musculus). In this study, senggani leaf infusion was used with a concentration of $0.1 \mathrm{~g} / \mathrm{ml}, 0.2$ $\mathrm{g} / \mathrm{ml}, 0.4 \mathrm{~g} / \mathrm{ml}$, aquadest as a negative control and glibenclamide suspension as a positive control.

The test material of this study was senggani (Melastoma malabathricum L.) leaves which were taken from the Mala-mala sub-district, North Kolaka Regency, then washed clean and cut into small pieces and dried to make a powder. Furthermore, Melastoma malabathricum L. were weighed and extracted using the infusion method.

In this study there were 5 treatment groups. Group I was given aquadest as a negative control, group II was given Senggani leaf infusion $0.1 \mathrm{~g} / \mathrm{ml}$, group III was given Senggani leaf infusion $0.2 \mathrm{~g} / \mathrm{ml}$, and group IV was given Senggani leaf infusion $0.4 \mathrm{~g} / \mathrm{ml}$ and group V given glibenclamide suspension as a positive control.

To determine the strength of the effect caused by the test preparation, Glibenclamide was used as a comparison which is an oral antidiabetic of the sullfonilurea class. Glibenclamide also has a strong hypoglycemic effect at a low dose and is able to stimulate the secretion of insulin in the pancreas, this drug is absorbed quickly and well so that it can be administered orally. This drug is suspended with Na.CMC $1 \% \mathrm{w} / \mathrm{v}$ because it is difficult to dissolve in water.

Determination of the effect of lowering blood sugar levels was carried out enzymatically using the oral glucose tolerance method. Blood is drawn through a vein at the end of the tail and then dripped on a glucometer strip. Blood droplets containing glucose will react with certain substances contained in the strip (glucose oxidase). Then automatically within 5 seconds the glucose level will be measured and the results can be read on the glucometer monitor.

The test animals used in this study were male mice because it was known that male mice had a more stable hormonal system than female mice which had higher blood glucose levels during pregnancy because of an increase in hormones including lactogen, placenta, cortisol, prolactin and progesterone. In addition, nutritional needs during pregnancy increase so that more glucose is produced than when not pregnant so that it can affect the results of the study.

Prior to treatment, the mice were fasted 3-4 hours to eliminate the biological effect of the test animals that could not be eliminated so that they could relatively affect the results of the study. Then the glucose levels were measured in the mice by taking the blood from the tip of the mice and then dropping them on a strip glucometer. After that the mice were then induced with a glucose solution of $20 \% \mathrm{w} / \mathrm{v}$ to raise the blood glucose levels of the test animals until the 
hyperglycemic condition. Then after 60 minutes of giving glucose laruyan, the mice were again measured for their blood sugar levels, after that they were immediately given the drug according to the predetermined group.

Based on the results of the study, it can be seen in the table that the fasting blood glucose levels of mice for each group were in the normal blood glucose range. According to Malole, normal blood sugar levels in mice are 62-175 mg / dl. After 1 hour of induction with a $20 \%$ glucose solution, it can be seen in the table that blood glucose levels in mice have increased. This shows that there has been absorption of glucose by the body of the mice so that they reach a hyperglycemic state.

The observations obtained were that in group I, namely giving negative control with aquadest, the average value was $16 \%$. For group II, with $0.1 \mathrm{~g} / \mathrm{ml}$ senggani leaf infusion, the average value obtained was $48.5 \%$, while for group III with $0.2 \mathrm{~g} / \mathrm{ml}$ senggani leaf infusion, the average value was $54.4 \%$., in group IV with the administration of senggani leaf infusion $0.4 \mathrm{~g} / \mathrm{ml}$ obtained an average of $65.4 \%$. For group V, with glibenclamide supposition as a positive control, the average decrease in blood sugar was $71.9 \%$.

The results showed that senggani leaf infusion at all concentrations had an effect on reducing blood sugar. However, Senggani leaf infusion at a concentration of $0.4 \mathrm{~g} / \mathrm{ml}$ gave the greatest / most optimal reduction effect compared to concentrations of $0.1 \mathrm{~g} / \mathrm{ml}$ and $0.2 \mathrm{~g} / \mathrm{ml}$. Glibenclamide suspension gives a greater blood sugar-lowering effect and for aquadest it does not have a significant effect on reducing blood glucose to the normal blood glucose range.

Glibenclamide blood glucose-lowering effect is greater because it includes a patent drug or medical drug that has gone through several tests with an effect on lowering blood sugar. Meanwhile, Senggani leaf infusion is still in the form of an extract, the concentration of which is not known for sure on the effect of lowering blood sugar and further research is needed to determine the effect of lowering blood sugar is greater.

Calculations obtained by statistical calculation methods, from the ANOVA test results obtained $\mathrm{p}$ value $<0.05(0.00<0.05)$, which means that senggani leaf infusion has a significant effect on reducing blood sugar in mice. To find out which groups were different, a post hoct test was carried out with the Tukey LSD, from the data obtained a significant difference, namely ( $\mathrm{p}$ value $<0.05)$.

The LSD test data showed that the negative control with $0.1 \mathrm{~g} / \mathrm{ml}$ infusion showed a significant difference ( $\mathrm{p}<0.05$ ), between negative control and $0.2 \mathrm{~g} / \mathrm{ml}$ infusion showed a significant difference. significant ( $\mathrm{p}<0.05$ ), between negative controls with infusion of $0.4 \mathrm{~g} / \mathrm{ml}$ showed a significant difference $(\mathrm{p}<0.05)$, between negative controls and positive controls showed a significant difference ( $\mathrm{p}<0.05$ ), between $0.1 \mathrm{~g} / \mathrm{ml}$ infusion and $0.2 \mathrm{~g} / \mathrm{ml}$ infusion showed no significant/non-significant difference $(\mathrm{p}>0.05)$, between $0.1 \mathrm{~g} / \mathrm{ml}$ infusion and 0.4 infusion $\mathrm{g} /$ $\mathrm{ml}$ showed a significant difference $(\mathrm{p}<0.05)$, between $0.1 \mathrm{~g} / \mathrm{ml}$ infusion and positive control showed a significant difference ( $\mathrm{p}<0.05$ ), between the infusion of $0.2 \mathrm{~g} / \mathrm{ml}$ with $0.4 \mathrm{~g} / \mathrm{ml}$ infusion showed a significant difference $(\mathrm{p}<0.05)$, between $0.2 \mathrm{~g} / \mathrm{ml}$ infusion and positive control showed a significant difference $(\mathrm{p}<0.05)$, and between infusions. $0.4 \mathrm{~g} / \mathrm{ml}$ with positive control also showed a significant difference $(\mathrm{p}<0.05)$. 


\section{Conclusion}

Based on the results of research on the blood sugar-lowering effect of senggani leaf infusion on mice, it can be concluded that Senggani leaf infusion can reduce blood sugar levels where the effectiveness of the reduction is at a concentration of $0.1 \mathrm{~g} / \mathrm{ml}$ of $48.5 \%, 0.2 \mathrm{~g} / \mathrm{ml}$ of $54.4 \%$, and $0.4 \mathrm{~g} / \mathrm{ml}$ at $65.4 \%$.

\section{References}

Ahrén, B. (2003). Gut peptides and type 2 diabetes mellitus treatment. Current diabetes reports, $3(5), 365-372$.

Arukwe, U., Amadi, B. A., Duru, M. K. C., Agomuo, E. N., Adindu, E. A., Odika, P. C., ... \& Anudike, J. (2012). Chemical composition of Persea americana leaf, fruit and seed. Ijrras, 11(2), 346-349.

Ban, T. A. (2001). Pharmacotherapy of depression: a historical analysis. Journal of neural transmission, 108(6), 707-716.

Brahmachari, G. (2011). Bio-flavonoids with promising antidiabetic potentials: A critical survey. Research signpost, 661(2), 187-212.

Farnsworth, N. R., Akerele, O., Bingel, A. S., Soejarto, D. D., \& Guo, Z. (1985). Medicinal plants in therapy. Bulletin of the world health organization, 63(6), 965.

García-Sevillano, M. A., García-Barrera, T., Navarro, F., Abril, N., Pueyo, C., López-Barea, J., \& Gómez-Ariza, J. L. (2015). Combination of direct infusion mass spectrometry and gas chromatography mass spectrometry for toxicometabolomic study of red blood cells and serum of mice Mus musculus after mercury exposure. Journal of Chromatography $B, 985,75-84$.

Hotchkiss, R. S., \& Karl, I. E. (2003). The pathophysiology and treatment of sepsis. New England Journal of Medicine, 348(2), 138-150.

Hu, F. B., Manson, J. E., Stampfer, M. J., Colditz, G., Liu, S., Solomon, C. G., \& Willett, W. C. (2001). Diet, lifestyle, and the risk of type 2 diabetes mellitus in women. New England journal of medicine, 345(11), 790-797.

Jeffreys, M., Capehart, B., \& Friedman, M. J. (2012). Pharmacotherapy for posttraumatic stress disorder: review with clinical applications. Journal of Rehabilitation Research \& Development, 49(5).

Johnny, L., Yusuf, U. K., \& Nulit, R. (2010). The effect of herbal plant extracts on the growth and sporulation of Colletotrichum gloeosporioides. Journal of Applied Biosciences, 34, 2218-2224.

Marianne, M., Yuandani, Y., \& Rosnani, R. (2011). Antidiabetic activity from ethanol extract of Kluwih's leaf (Artocarpus camansi). Jurnal Natural, 11(2).

Mellitus, D. (2005). Diagnosis and classification of diabetes mellitus. Diabetes care, 28(S37), S5-S10.

Shaw, J. E., Sicree, R. A., \& Zimmet, P. Z. (2010). Global estimates of the prevalence of diabetes for 2010 and 2030. Diabetes research and clinical practice, 87(1), 4-14. 
Unger, R. H. (2008). Reinventing type 2 diabetes: pathogenesis, treatment, and prevention. Jama, 299(10), 1185-1187.

Van Stennis, C. G. G. J. (1975). Flora untuk sekolah di Indonesia. Terjemahan dari Flora oleh Moeso Sarjowinoto. Pradnya Paramita, Jakarta.

Visser, J. C., Woerdenbag, H. J., Crediet, S., Gerrits, E., Lesschen, M. A., Hinrichs, W. L., ... \& Frijlink, H. W. (2015). Orodispersible films in individualized pharmacotherapy: The development of a formulation for pharmacy preparations. International journal of pharmaceutics, 478(1), 155-163. 